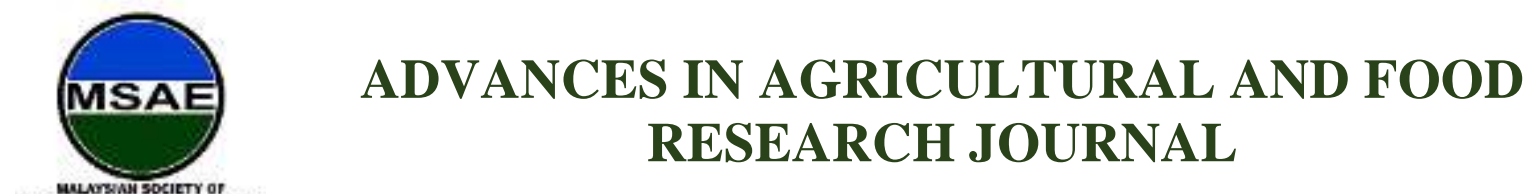

HHPUBLISHER

Editorial Note

\title{
Agricultural and Food Industries in Malaysia
}

\author{
Rosnah Shamsudin ${ }^{1} \&$ Christine Jamie Vincent ${ }^{1}$ \\ ${ }^{1}$ Department of Process \& Food Engineering, Faculty of Engineering, Universiti Putra Malaysia, Serdang, \\ 43400 Serdang Malaysia. \\ *Corresponding author: Rosnah Shamsudin, Department of Process \& Food Engineering, Faculty of \\ Engineering, Universiti Putra Malaysia, Serdang, 43400 Serdang Malaysia; rosnahs@upm.edu.my
}

Received: $25^{\text {th }}$ July 2020

Accepted: $14^{\text {th }}$ August 2020

Published: $24^{\text {th }}$ August 2020

Citation: Shamsudin $\mathrm{R}$ \& Vincent CJ. Agricultural and food industries in Malaysia. Adv Agri Food Res J 2020; 1(1): a0000107. https://doi.org/10.36877/aafrj.a0000107

\section{Main Text}

Recent studies on the export of processed food in Malaysia have shown obvious increments in the acceptance of its food products in the overseas market. Malaysia consists of a very diverse population which contributes to the wide selection of unique food products produced locally. This opens a window for Malaysia to become a major exporter in the Association of Southeast Asian Nations (ASEAN) region where it is reported to have a population of over 600 million. Furthermore, with the country's major population being Muslims, it also provides the opportunity for the country to be positioned as an internationalready domestic market for halal food in the global market. Developments in the agricultural and agro-food processing sector in Malaysia have placed Malaysia among the leading ASEAN countries for the food and beverage industry, but to-date only big key players are able to benefit from these strong value propositions as currently, most business establishments in Malaysia are Small Medium Enterprises (SME) and there is still a huge lack in locally produced agricultural and agro-food processing machinery that could be of great help to the SMEs. To cater to the bulk production for the global market, there is a great need for new machines to be invented so that the cottage industries and SMEs could expand and sustain their business in the long run. Universities and research centres in Malaysia play important roles in the development of these machines that are able to complement the smallmedium enterprises especially the cottage industries that are currently producing food and agricultural products in a smaller scale due to the lack of modernization involved. It is also crucial to sustain its position as one of the top countries for the exports of Halal food products. It is hoped that with these inventions, the small-medium enterprises involved in the cottage industry that are producing food products would not only benefit from the inventions but also increase the socio-economy of these business owners.

Malaysia is famous for its lush tropical lands and naturally grown resources that are utilised widely for cultivation, research and processing of foods, hence, agriculture is a sector 
that contributes greatly to the nation's resources and wealth. The climate in Malaysia also allows for the sustainable supply of agricultural products throughout the whole year. The agriculture industry in Malaysia comprises of industrial commodities and agro-food. Palm oil, rubber and cocoa are planted on a large scale and therefore considered as industrial commodities. Agro-food which is mostly planted by smallholders and most of the time categorised under the Small Medium Enterprises (SMEs), include rice, fruits, vegetables, fisheries and livestock. These commodities are sent to small industries to be distributed to traders, hypermarkets and local sundry shop owners. Foodstuff is processed into food products such as chilli sauce, cereals and dairy products, while bakeries utilise eggs to produce cakes, pastries and cookies. There are many other commodities and trades in the Malaysian food and beverage industry. The increase in the production of agricultural productions is attributed to the development of the agricultural sector.

In Malaysia, the main economy generators are the Small and Medium Enterprises (SMEs) (Jamak et al., 2011; Lo et al., 2016; SME Corporation, 2015). According to the Department of Statistics Malaysia in July 2019, more than half of the total workforce in the country $(\sim 65 \%)$ consisted of business establishments in the Small Medium Enterprises (SMEs) category with the percentage of $98.5 \%$, of which $21.2 \%$ were small businesses and $76.5 \%$ were micro-enterprises (Ramli \& Taib, 2017). According to the definition of SMEs by the Central Bank of Malaysia (2015), SMEs are categorised into Micro, Small and Medium enterprises based on the number of employees and the total annual sales generated. The data provided by the SME Corp of Malaysia stated that SMEs contributed an average of about $36.6 \%$ of Gross Domestic Product (GDP) with an increment in total exports of $18.6 \%$ from $17.7 \%$ in 2016. It is of utmost importance to recognise the success formula of SMEs in these contributions to Malaysia's economic development and to try and maximise the growth further with necessary measures, be it in the advancement of the technology used or in the business performance itself.

According to the Malaysian Industrial Development Authority (MIDA) in its article entitled Food Industry in Malaysia (2019), processed food in Malaysia contributed about RM 21.1 billion and was exported to more than 200 countries, while import value of processed food amounted to RM 20.7 billion in 2017. It was deduced that Malaysia's Food Product recorded a growing acceptance in the global market due to the increasing number of processed food exports throughout the years. Malaysia consists of a very diverse population which contributes to the wide selection of unique food products produced locally. This opens a window for Malaysia to become a major exporter in the Association of Southeast Asian Nations (ASEAN) region of which it is reported to have a population of over 600 million. Furthermore, with the country's major population being Muslims, it also provides the opportunity for the country to be positioned as an international-ready domestic market for halal food in the global market. Developments in the agricultural and agro-food processing sector in Malaysia have placed Malaysia among the leading ASEAN countries for the food and beverage industry, but to-date the food-processing sector is only $10 \%$ of Malaysia's 
manufacturing output. These $10 \%$ consist of mostly only big key players who are able to benefit from these strong value propositions as at present, most business establishments in Malaysia are Small Medium Enterprises (SME) and there is still a huge lack in locally produced agricultural and agro-food processing machinery that could be of great help to the SMEs.

On the other hand, the halal food industry conforms to the Syariah compliance and this promises the Muslims globally a sense of security for whatever they buy and use (Bohari et al., 2013). Moreover, it is also crucial for societal development and national economic growth. The Malaysian government applied for the single Halal standard throughout the country and so was dubbed and cited by the United Nations as the world's best example of benchmarking of halal food in accordance with the Codex Alimentarius Commission adopting the Codex general guidelines for the use of the term halal in Geneva in 1997. Not only that but the Halal food market is also gaining attention amongst the non-Muslims as well for its symbol that indicates quality and safety (Talib, \& Mohd Ali, 2009). As for the current halal industry in the global market, MIDA estimates the industry to be at US\$ 2.3 trillion and since Malaysia's major population is Muslims, it is well-positioned as an international-ready domestic market for halal food. These strong value propositions open up opportunities for the food processing industry.

In order to strengthen the advancement of agricultural and food industries, the Advances in Agricultural and Food Research Journal (AAFRJ) has been generated. This journal is aimed to spread the awareness of knowledge and new development of technologies in agriculture and food industries. AAFRJ is an open access international journal that publishes original research and review papers on any subject related to science and engineering in agriculture and food, particularly those of relevance to the industry. This can include applied agricultural, biological, environmental, natural resources, food and livestock farming to solve problems in complex living systems. In addition to science and engineering topics, we also welcome articles related to agriculture and food service extension, management and business either at the local or international level.

This journal is also an effort to continue in assisting farmers, entrepreneurs or industries related by enhancing the research and development in farming, harvesting, processing, manufacturing, quality, storage, sorting, product safety and services according to the good manufacturing process (GMP), enhancing coordination among the organisations involved in the development and promotion of agriculture and food, supply chain and many more. As the agricultural and food industries are growing rapidly, this journal might be one of the platforms for sharing, exchanging and transferring knowledge to the global industry.

Conflicts of Interest: The author declares no potential conflict of interest with respect to the research, authorship, and/or publication of this article.

\section{References}

Bohari, A.M., Hin, C.W., \& Fuad, N. (2013). The competitiveness of halal food industry in Malaysia: A SWOT-ICT 
analysis. Geografia Malaysia Journal of Society and Space, 9(1), 1-9.

Central Bank of Malaysia. (2015). Retrieved from http://www.bnm.gov.my/files/publicati on/ar/en/2015/ar2015_book.pdf

Jamak, A., Salleh, A. B. S., Sivapalan, R. S., \& Abdullah, A. (2011). Entrepreneurial challenges confronting microenterprise of Malaysian Malays. World Academy of Science, Engineering and Technology, 5(9), 862-867.

Lo, M. C., Wang, Y. C., Wah, C. R. J., \& Ramayah, T. (2016). The critical success factors for organizational performance of SMEs in Malaysia: A partial least squares approach. Review of Business Management, 18(61), 370-391.

MIDA. (2019). Food industry in Malaysia. Retrieved from https://www.mida.gov.my/home/33/pages/

Ramli, A. \& Taib, M. (2017). Malaysian Malay micro businesses: Success factors in Langkawi Island. Science International (Lahore), 29(6), 1191-1198.

SME Corporation Malaysia. (2017). Micro Enterprises. Retrieved from https://www.smecorp.gov.my/index.php /en/

SME Corporation Malaysia. (2015). About SME Masterplan (2012-2020). Retrieved on June 19, 2020, from http://www.smecorp.gov.my/index.php/en/policies/2 015-12-21-09-16-12/about-sme-masterplan (2015).

Talib, H.A. \& Mohd Ali, K.A. (2009). An overview of Malaysian food industry: The opportunity and quality aspects. Pakistan Journal of Nutrition, 8, 507-517.

Copyright (C 2020 by Shamsudin R. et al. and HH Publisher. This work is licensed under the Creative Commons Attribution-NonCommercial 4.0 International Licence (CC-BY-NC4.0). 